\title{
Maciej Walczak*
}

(iD) https://orcid.org/0000-0003-4604-620X

\section{Optymalizacja rozmieszczenia stanowisk w komórce U-ksztaltnej z zastosowaniem programowania sieciowego i metody trójkątów Schmigalli $^{1}$}

Streszczenie: Rozmieszczenie stanowisk roboczych ma istotne znaczenie z punktu widzenia kosztów i czasu realizacji procesów produkcyjnych. Obecnie istnieje zarówno szereg modeli rozmieszczenia, jak i metod jego optymalizacji. Jednym z takich modeli, wykorzystywanym przy projektowaniu komórek produkcyjnych, jest rozmieszczenie U-kształtne ( $U$-shaped). Rozmieszczenie U-kształtne stało się popularne za sprawą koncepcji odchudzonej produkcji.

Celem opracowania jest ukazanie możliwości optymalizacji rozmieszczenia stanowisk w linii U-kształtnej z wykorzystaniem metody programowania sieciowego i trójkątów Schmigalli.

Słowa kluczowe: optymalizacja rozmieszczenia, rozmieszczenie stanowisk, komórki U-kształtne, zarządzanie produkcją, $U$-shaped, one piece flow, lean, metoda Schmigalli.

\section{Wstęp}

Optymalizacja działania w czasie i przestrzeni stanowiła od zawsze ważny obszar rozważań w naukach organizacji i zarządzania. W procesach produkcyjnych dąży się do minimalizacji czasu wytworzenia produktu, przestrzeń z kolei jest najczęściej rozpatrywana z punktu widzenia minimalizacji odległości, jaką przebywa określony materiał w procesie prowadzącym do powstania wyrobu finalnego. Szacuje się, że 30-70\% całkowitych kosztów wytworzenia produktu to wydatki związane z jego

* Uniwersytet Ekonomiczny w Krakowie, walczakm@uek.krakow.pl

1 Publikacja została sfinansowana ze środków przyznanych Kolegium Nauk o Zarządzaniu i Jakości Uniwersytetu Ekonomicznego w Krakowie w ramach dotacji na utrzymanie potencjału badawczego. 
przemieszczaniem, co może stanowić $20-50 \%$ całkowitych kosztów operacyjnych $\mathrm{w}$ przedsiębiorstwach produkcyjnych [Banduka, Mladineo, Eric, 2017: 375]. Doskonalenie struktury przestrzennej należy zatem postrzegać poprzez pryzmat źródła poprawy efektywności gospodarowania w przedsiębiorstwie [Prońko, Soboń, Zamiar, 2008: 215].

W przypadku produkcji masowej, w której rozpatrywany jest przebieg tylko jednego wyrobu o niezmiennej marszrucie, bardzo dobre rezultaty uzyskiwane są poprzez zastosowanie synchronicznych linii produkcyjnych. Sytuacja jest zdecydowanie bardziej skomplikowana w warunkach produkcji seryjnej, gdy marszruty dla poszczególnych pozycji asortymentowych różnią się liczbą i kolejnością realizowanych operacji. Problem dotyczy również gniazd przedmiotowych wykorzystujących technologię grupową, gdzie przebieg produkcji (marszruta) ulega modyfikacji wraz ze zmianami w jej wielkości w ustalonym typoszeregu wyrobów [Brzeziński, 2002: 167].

Przemieszczanie materiału w procesie produkcyjnym (w szczególności zbędne), jak również niepotrzebny ruch pracowników, zostały sklasyfikowane przez Taiichi Ohno - jednego z twórców koncepcji produkcji odchudzonej (lean production) - jako dwa z siedmiu rodzajów marnotrawstwa (muda). Redukcja wspomnianych strat następuje między innymi poprzez optymalizację rozmieszczenia stanowisk. Optymalizacja taka prowadzona jest $\mathrm{w}$ oparciu o doświadczenie osób projektujących komórki organizacyjne lub z zastosowaniem metod przestrzennego organizowania procesów pracy [Zielecki, Sęp, 2014: 682]. Możliwy jest również wariant pośredni, gdy opracowane $\mathrm{z}$ wykorzystaniem wybranej metody rozmieszczenie jest dostosowywane do określonych wymagań i wytycznych przez projektanta. Wyróżnianych jest pięć typów rozmieszczenia [Waters, 2001: 235]: technologiczne, przedmiotowe, mieszane (inaczej nazywane hybrydowym, czyli połączenie technologicznego z przedmiotowym), stałe, specjalistyczne (stosowane w przypadkach prowadzenia określonego rodzaju działalności, np. hurtownia, sklep). Z kolei, w ramach optymalizacji rozmieszczenia stanowisk, wykorzystuje się takie metody ${ }^{2}$ jak [Martyniak, 1999: 122-123]: trójkątów Schmigalli, „ogniw”, CORELAP (Computerized Relationship Layout Planning), CRAFT (Computerized Relative Allocation of Facilities Technique), podziału i ograniczeń Gavetta i Plytera, metody wykorzystujące teorię grafów kołowych, a także HC 66 (Hillera-Connorsa), MAT (Modular Allocation Technique) i SLP (Systematic Layout Planning).

2 Szerzej o metodach rozmieszczania stanowisk i ich klasyfikacji m.in. M. Dudek [2016: 292-306]. 
Wśród szeregu klasyfikacji metod optymalizacji przestrzennego rozmieszczenia obiektów wyróżniane są m.in. metody jednokryterialne (np. metoda trójkątów Schmigalli) i wielokryterialne (np. metoda SLP). W przypadku metod jednokryterialnych optymalizacja jest prowadzona przy wykorzystaniu funkcji celu pod postacią [Potocki, 1993: 40]:

gdzie:

$$
Q=\sum_{i=1}^{N} \sum_{j=1}^{N} S_{i j} L_{i j} \rightarrow \text { minimum }
$$

$S_{i j}$ - powiązania między obiektem ,i, a obiektem ,j”,

$L_{i j}$ - odległość (mierzona w przyjętych jednostkach modułowych) między obiektem ,i" a obiektem ,j”".

Z uwagi, że tak skonstruowana funkcja kryterium odzwierciedla poziom kosztów związanych z realizacją przemieszczeń w badanym układzie stanowisk, przy optymalizacji dąży się do znalezienia takiego ich rozmieszczenia, przy którym wartość funkcji będzie najmniejsza. Uwzględnianie tylko jednego kryterium $\mathrm{z}$ jednej strony upraszcza tok postępowania, $\mathrm{z}$ drugiej zaś stanowi istotne ograniczenie metod jednokryterialnych.

Z kolei w przypadku metod wielokryterialnych, kluczową trudnością przy optymalizacji rozmieszczenia obiektów może być występowanie sprzeczności pomiędzy niektórymi z przyjętych kryteriów [Prońko, Soboń, Zamiar, 2008: 217].

Jednym $\mathrm{z}$ wariantów $\mathrm{w}$ zakresie przestrzennego organizowania procesu pracy jest zastosowanie U-kształtnego (U-shaped) lub S-kształtnego (S-shaped) układu stanowisk wewnątrz komórki produkcyjnej. Wspomniane układy rozmieszczenia wspomagają ideę przepływu ciągłego poprzez zastosowanie przepływu rytmicznego, w którym redukowane są do minimum wszelkie przestoje w przepływie materiałów i półwyrobów a także ograniczone zapasy międzyoperacyjne [Matusek, 2012: 193]. Do najczęściej stosowanych kształtów rozmieszczenia jednostek produkcyjnych w strukturach elastycznych należą: linia, kształt L, kształt U i okrąg. Rozmieszczenia te często są dostosowywane do potrzeb i dostępnej powierzchni [Pająk, 2006: 180, 182].

Celem opracowania jest przedstawienie możliwości wykorzystania programowania sieciowego oraz metody trójkątów Schmigalli do optymalizacji rozmieszczenia stanowisk w produkcyjnej komórce U-kształtnej. Zastosowaną metodą badawczą była analiza dostępnej literatury powiązanej z problemem oraz symulacja wykorzystania wskazanych metod 
na modelu siedmiostanowiskowej linii produkcyjnej. Badanie przeprowadzone na modelu stało się podstawą oceny efektów optymalizacji rozmieszczenia stanowisk osiągniętych w wyniku użycia obu metod.

\section{Istota rozlokowania stanowisk w komórkach U-ksztaltnych}

Rozmieszczenie stanowisk jest określane U-kształtnym, jeżeli miejsce, w którym ciąg stanowisk opuszczają elementy po obróbce znajduje się w pobliżu miejsca, gdzie są one wprowadzane do tego ciągu [Ohno, Nakade, 1997: 90]. Katsuhisa Ohno i Koichi Nakade wskazują ponadto, że jeżeli ten sam robotnik obsługuje zarówno stanowisko na wejściu, jak i na wyjściu tego ciągu, to takie rozmieszczenie należy określać mianem U-kształtnej linii produkcyjnej [Ohno, Nakade, 1997: 90; Özgürler, Güneri, Gülsün, Yilmaz, 2010: 253]. Pracownicy w tym układzie realizują swoje zadania wewnątrz powstałej w ten sposób linii. Przy projektowaniu nie przewiduje się nawrotów materiału, natomiast pomijanie stanowisk jest możliwe. Istotę rozmieszczenia U-kształtnego prezentuje rysunek 1.

W komórce U-kształtnej maszyny są rozmieszczone w taki sposób, że pracownicy znajdują się wewnątrz komórki. Zaopatrzenie dostarczane jest zazwyczaj tak, aby nie było konieczności realizacji związanych z nim czynności transportowych po trasach którymi przemieszczają się obsługujący komórkę pracownicy, czyli z zewnątrz tak powstałej litery U. Zasadniczą zaletą komórek U-kształtnych jest redukcja odległości, które pokonują pracownicy przy przechodzeniu pomiędzy maszynami znajdującymi się w komórce. Częste przejścia są wymuszone stosowaniem obsługi wielomaszynowej, na co pozwala szeroki zakres umiejętności posiadanych przez poszczególnych pracowników. Kolejną zaletą tego typu rozwiązania jest łatwość regulacji poziomu produkcji w komórce poprzez zwiększanie lub zmniejszanie liczby obsługujących ją pracowników. 


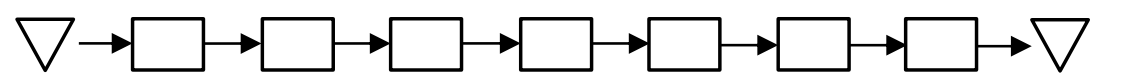

a)
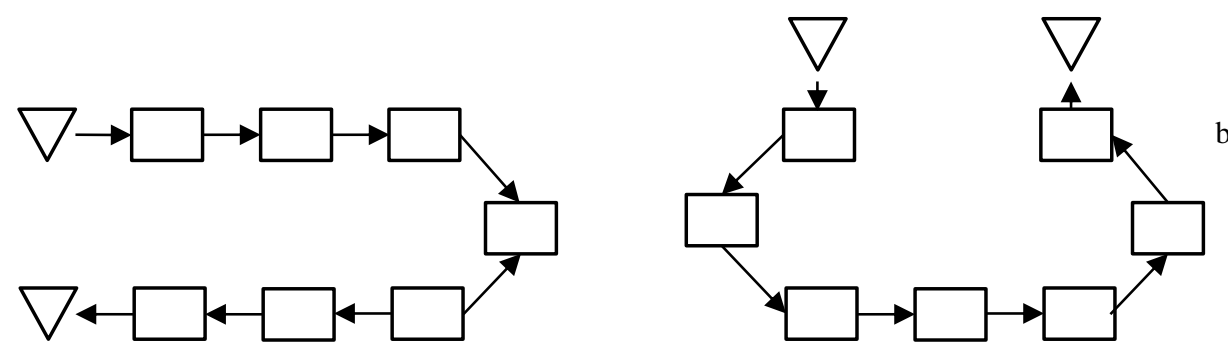

b)

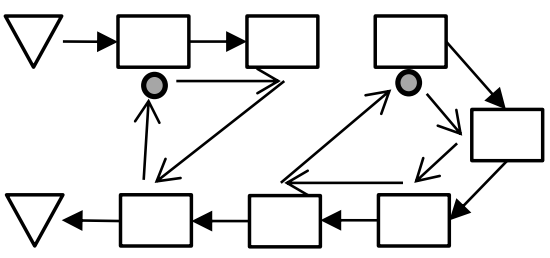

c)

Legenda:

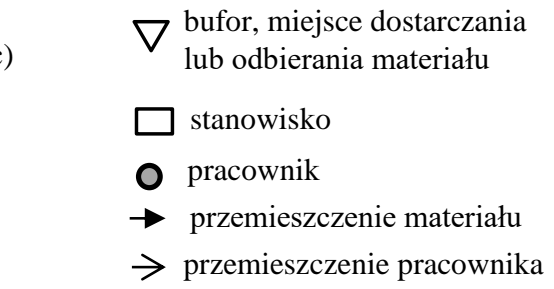

Rysunek 1. Rozmieszczenie stanowisk w: a) linii produkcyjnej jednorzędowej, b) linii produkcyjnej U-kształtnej, c) linii produkcyjnej U-kształtnej obsługiwanej przez dwóch pracowników z zaznaczonymi trasami przemieszczania się pomiędzy stanowiskami

Źródło: opracowanie własne na podstawie W. Zielecki, J. Sęp [2014: 683];

K. Ohno, K. Nakade [1997: 91]; M. Dudek [2016: 310].

Rozmieszczenia U- i S-kształtne z powodzeniem wykorzystywane są w systemach produkcyjnych JiT (just-in-time) w przypadku, gdy na danej linii wykonywane są zróżnicowane, niewielkie elementy i nie zachodzi potrzeba wykorzystywania pojemników transportowych przy ich przemieszczaniu [Ohno, Nakade, 1997: 90]. Przy założeniu, że w linii U-kształtnej realizowane będzie wytwarzanie elementów o niewielkich wymiarach i masie, ich przemieszczanie odbywa się po jednym elemencie przenoszonym w rękach. Dlatego też rozmieszczenie tego typu wpisuje się w koncepcję przepływu jednej sztuki (one piece flow) (rysunek 2), stanowiącej jedno z założeń koncepcji odchudzonego wytwarzania (lean manufacturing). 


\section{rozmieszczenie}

podporządkowane

projektowi, bardzo duże

zróżnicowanie przepływu

rozmieszczenie

technologiczne,

przepływ zróżnicowany

rozmieszczenie komórkowe, przepływ zróżnicowany ze

schematami

linia U-kształtna,

przepływ zróżnicowany,

system ciągniony,

takt produkcji

linia,

przepływ mało zróżnicowany,

produkcja cykliczna,

takt produkcji

linia,

przepływ niezmienny,

stałe tempo
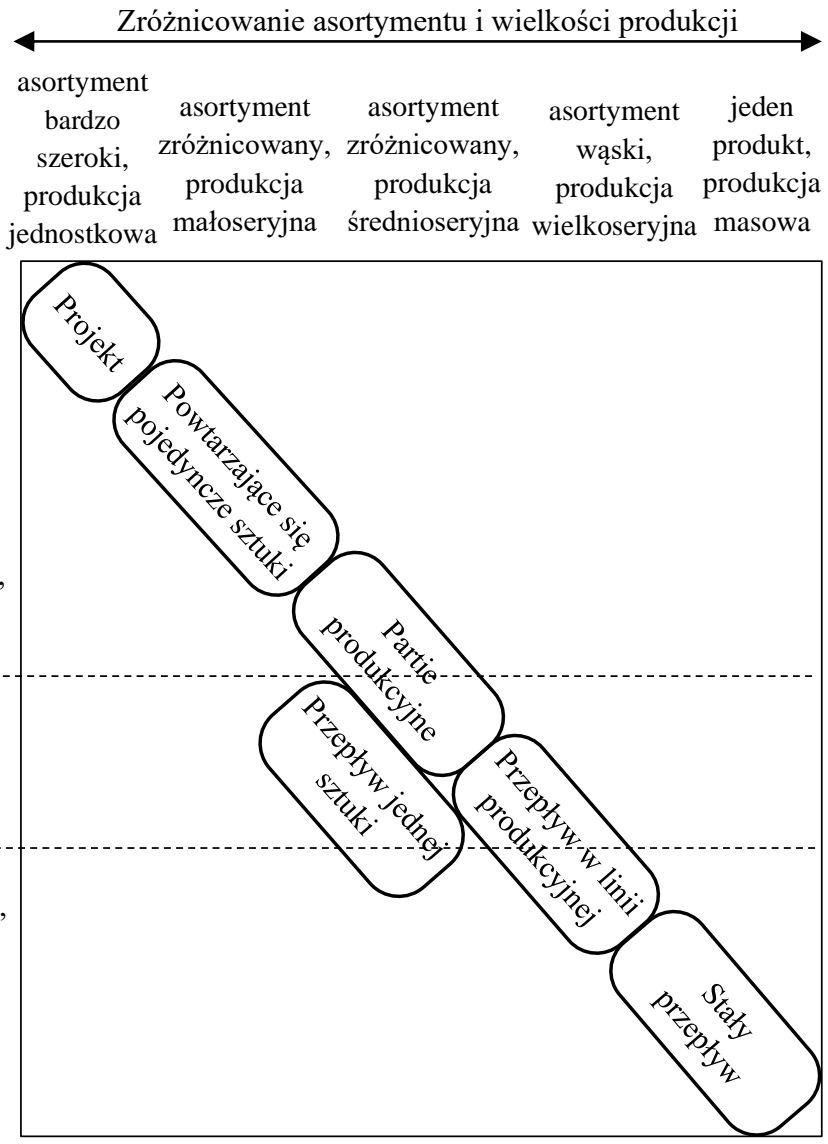

Rysunek 2. Umiejscowienie idei przepływu jednej sztuki

Źródło: opracowanie własne na podstawie J. Miltenburg [2001: 304].

W ramach optymalizacji funkcjonowania linii U-kształtnej branych jest pod uwagę szereg czynników, wśród których do najważniejszych należy zaliczyć: liczbę obsługujących komórkę pracowników, przypisanie operacji do pracowników, rozmieszczenie stanowisk w komórce. 


\section{Metody optymalizacji rozmieszczenia stanowisk w układzie U-kształtnym}

Problem optymalizacji rozmieszczenia stanowisk w linii U-kształtnej występuje w przypadku produkcji asortymentu wyrobów, których marszruta różni się pod względem wykonywanych operacji. Ponieważ stanowiska tworzą linię, projektując przebieg materiału zakłada się brak możliwości nawrotu przedmiotu pracy w procesie.

Władysław Zielecki i Jarosław Sęp, prezentując możliwości zastosowania programowania sieciowego w obszarze optymalizacji rozmieszczenia stanowisk w liniach U-kształtnych, posłużyli się algorytmem Forda [2014: 686]. W przedstawionym toku postępowania w pierwszym kroku dokonali transformacji linii jednorzędowej w linię U-kształtną poprzez zbliżenie ze sobą pierwszego i ostatniego stanowiska. Zmiana ta istotnie zredukowała wartość funkcji celu (w przeprowadzonej przez autorów symulacji o 13,8\%). W kolejnym kroku dokonano optymalizacji rozmieszczenia stanowisk z zastosowaniem programowania sieciowego (algorytm Forda). W tym celu linię U-kształtną utworzono ze stanowisk znajdujących się na ścieżce krytycznej. Stanowiska spoza tej ścieżki zostały umieszczone $\mathrm{w}$ połowie linii U-kształtnej. W rezultacie nastąpiła ponowna redukcja funkcji celu (w symulacji do wartości o 19,4\% mniejszej w porównaniu $\mathrm{z}$ linią jednorzędową ${ }^{3}$ ).

Wspomniani autorzy wskazują również na możliwość wykorzystania, celem optymalizacji rozmieszczenia stanowisk, japońskiej metody 3P (Production, Preparation, Process). Celem tej metody jest wprowadzenie radykalnych zmian w produkcie lub procesie, natomiast tok postępowania zakłada jednoczesne projektowanie zarówno produktu, jak i związanego z nim procesu. Nacisk kładziony jest na pracę zespołową, poszukiwanie różnych propozycji rozmieszczenia stanowisk, tworzenia makiet przestrzennych i wyboru najlepszego wariantu [Zielecki, Sęp, 2014: 684-685].

Problematykę przestrzennej organizacji komórek U-kształtnych można rozpatrywać również z punktu widzenia minimalizacji odległości pokonywanych przez pracowników. Na przykład Ronnachai Sirovetnukul i Parames Chutima [2010] prowadzą szereg analiz pod kątem optymalizacji przydziału operacji do pracowników w przypadku różnych rozmieszczeń stanowisk w tego rodzaju komórkach.

3 W powoływanej pracy autorzy nie wskazali, jaki rodzaj siatki został wykorzystany w obliczeniach. 
Edward Pająk podkreśla jednak, że wykonywanie rozbudowanych obliczeń produkcyjnych, w tym związanych z rozmieszczeniem, w przypadku struktur elastycznych nie znajduje pełnego uzasadnienia [Pająk, 2006: 180]. Wynika to z faktu, że częste zmiany, związane z dostosowywaniem się do potrzeb rynku, dezaktualizują dane na podstawie których wyznaczane są optymalne rozwiązania.

\section{Porównanie efektów optymalizacji rozmieszczenia metodą programowania sieciowego i trójkątów Schmigalli}

W opracowaniu wykorzystano metodę programowania sieciowego (CPM) i trójkątów równobocznych Schmigalli. Celem oceny efektów zastosowania wymienionych narzędzi wykorzystano je do optymalizacji rozmieszczenia siedmiu stanowisk w komórce realizującej produkcję czterech wyrobów (A, B, C, D). Marszruty wyrobów oraz przewidywane zapotrzebowanie w badanym okresie na wyroby przedstawia tabela 1 .

Tabela 1. Marszruty i założona wielkość produkcji dla czterech wyrobów

\begin{tabular}{|c|c|c|c|c|c|c|c|c|}
\hline Wyrób & \multicolumn{7}{|c|}{ Marszruta (numer stanowiska) } & Liczba sztuk \\
\hline A & 1 & 2 & 3 & 4 & 5 & 6 & 7 & 10 \\
\hline B & 1 & 2 & & 4 & & 6 & 7 & 20 \\
\hline C & 1 & & 3 & & & 6 & 7 & 30 \\
\hline D & 1 & 2 & & 4 & & & 7 & 40 \\
\hline
\end{tabular}

Źródło: opracowanie własne.

Zakładając wykorzystanie przy lokowaniu stanowisk siatki trójkątów równobocznych, zoptymalizowane rozmieszczenie przybierze postać jak na rysunku 3 a) lub b). Wskazany układ będzie odpowiadał typowemu rozmieszczeniu w komórce U-kształtnej, czyli umieszczeniu stanowiska ostatniego w pobliżu stanowiska pierwszego. 


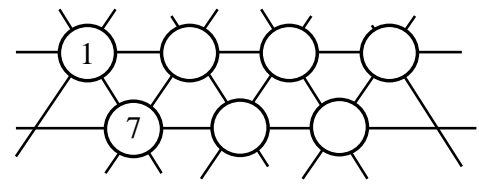

a)

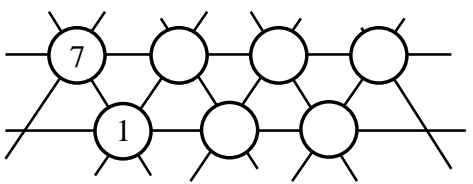

b)

Rysunek 3. Docelowy model rozmieszczenia dla komórki U-kształtnej Źródło: opracowanie własne.

Dane z tabeli 1 można przedstawić z wykorzystaniem grafu (rysunek 4), obrazującego zarówno ruch, jak i ilość materiału przemieszczanego pomiędzy poszczególnymi stanowiskami w komórce. Informacje te zawiera również macierz powiązań transportowych (Sij) (macierz 1).

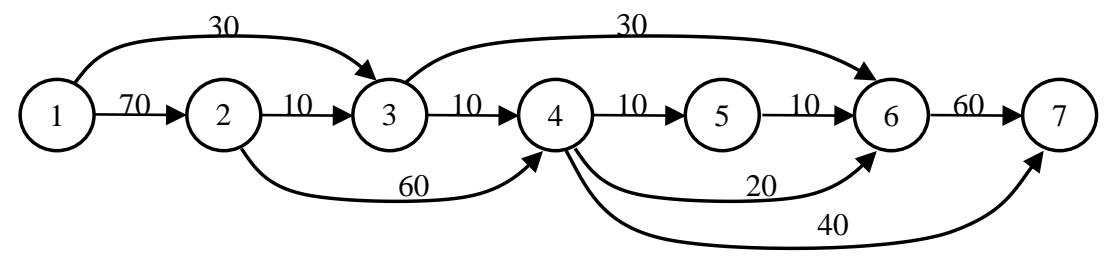

Rysunek 4. Schemat przepływ materiału w analizowanej komórce

Źródło: opracowanie własne.

$$
\left[S_{i j}\right]=\left[\begin{array}{cccccccc}
- & 70 & 30 & & & & \\
& - & 10 & 60 & & & \\
& & - & 10 & & 30 & \\
& & & - & 10 & 20 & 40 \\
& & & & - & 10 & \\
& & & & & - & 60 \\
& & & & & & -
\end{array}\right]
$$

Macierz 1. Powiązania transportowe pomiędzy stanowiskami Źródło: opracowanie własne. 
Przyjmując opisaną wcześniej funkcję celu $Q$, jako kryterium optymalizacji rozmieszczenia, niezbędne jest ustalenie powiązań transportowych oraz odległości pomiędzy stanowiskami dla każdej propozycji ich rozlokowania. Punkt wyjścia stanowi rozmieszczenie stanowisk w postaci linii jednorzędowej (rysunek 5), dla którego odległości między stanowiskami $\left(L_{i j}\right)$ kształtują się tak jak zaprezentowano to na macierzy 2.

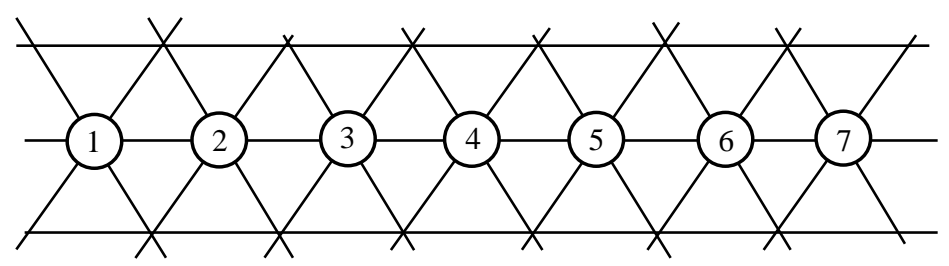

Rysunek 5. Rozmieszczenie stanowisk linii jednorzędowej na siatce trójkątnej (wariant 0)

Źródło: opracowanie własne.

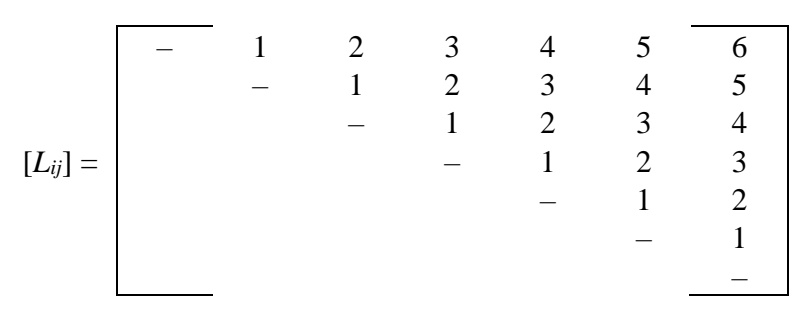

Macierz 2. Odległości między stanowiskami dla linii jednorzędowej

Źródło: opracowanie własne.

Dla linii jednorzędowej wartość Q wynosi 600 (suma iloczynów odległości pomiędzy stanowiskami liczonymi w modułach siatki trójkątnej i odpowiadających im powiązań transportowych). Najprostszym sposobem na przekształcenie linii jednorzędowej w komórkę U-kształtną jest ustawienie stanowisk tak, aby ostatnie znajdowało się w bezpośrednim sąsiedztwie pierwszego. Zmiana taka, bez analizy powiązań międzystanowiskowych, została przedstawiona na rysunku 6.

Wartości powiązań międzystanowiskowych nie ulegną zmianie, modyfikacja nastąpi w macierzy odległości (macierz 3). 


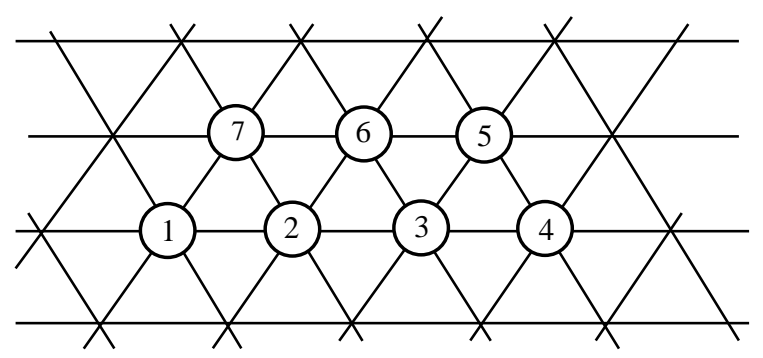

Rysunek 6. Rozmieszczenie stanowisk linii U-kształtnej na siatce trójkątnej (wariant 1)

Źródło: opracowanie własne.

$$
\left[\mathrm{L}_{\mathrm{ij}}\right]=\left[\begin{array}{cccccccc}
- & 1 & 2 & 3 & 3 & 2 & 1 \\
& - & 1 & 2 & 2 & 1 & 1 \\
& & - & 1 & 1 & 1 & 2 \\
& & & - & 1 & 2 & 3 \\
& & & & - & 1 & 2 \\
& & & & & - & & 1 \\
& & & & & & &
\end{array}\right.
$$

Macierz 3. Odległości pomiędzy stanowiskami dla wariantu 1

Źródło: opracowanie własne.

Odpowiadająca wariantowi 1 wartość funkcji celu, równa 540, jest wyraźnie mniejsza w porównaniu z linią jednorzędową.

Władysław Zielecki i Jarosław Sęp zaproponowali, aby na podstawie sieci przepływu w komórce zbudować jej model sieciowy i wyznaczyć ścieżkę krytyczną. Następnie ze stanowisk znajdujących się na ścieżce stworzyć linię U-kształtną, a pozostałe dostawić ,,z tyłu linii”" [Zielecki, Sęp, 2014: 686]. Zastosowanie toku postępowania z metody CPM, prowadzi do wyznaczenia ścieżki krytycznej składającej się ze stanowisk 1, 2, 4, 5, 6 i 7. Stanowisko 3 znalazło się poza ścieżką krytyczną (rysunek 7).

Jeżeli stanowiska zostaną rozmieszczone w linię U-kształtną według kryterium przynależności do ścieżki krytycznej, ich układ na siatce przyjmie postać jak na rysunku 8 . Rozmieszczeniu temu odpowiada macierz odległości 4.

4 Inaczej można określić, że pozostałe stanowiska zostaną umieszczone w połowie linii. 


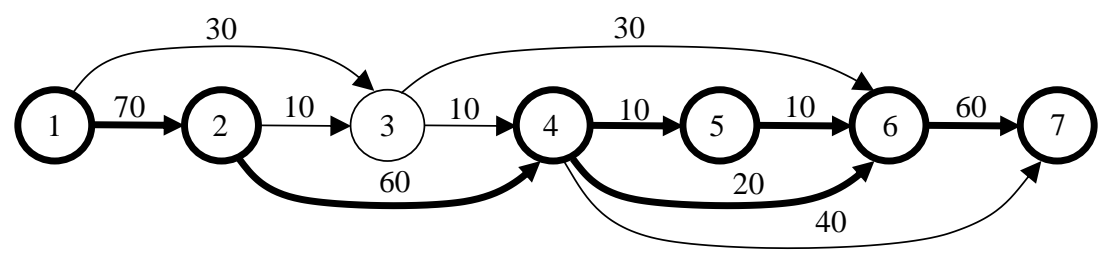

Rysunek 7. Ścieżka krytyczna dla analizowanej komórki

Źródło: opracowanie własne.

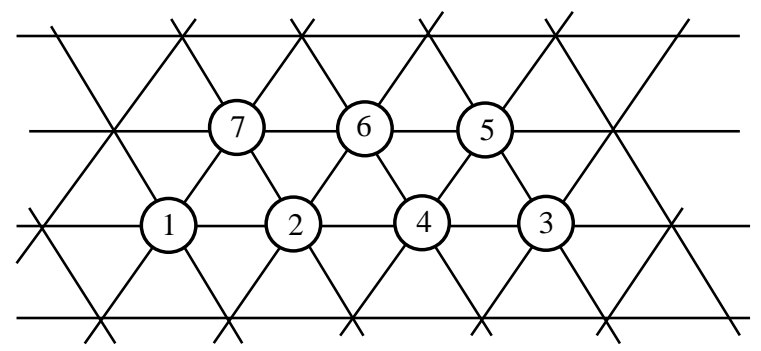

Rysunek 8. Stanowiska rozmieszczone zgodnie z kryterium przynależności do ścieżki krytycznej (wariant 2)

Źródło: opracowanie własne.

$$
\left[L_{i j}\right]=\left[\begin{array}{cccccccc}
- & 1 & 3 & 2 & 3 & 2 & 1 \\
& - & 2 & 1 & 2 & 1 & 1 \\
& & - & 1 & 1 & 2 & 3 \\
& & & - & 1 & 1 & 2 \\
& & & & - & 1 & 2 \\
& & & & & - & & - \\
& & & & & & &
\end{array}\right.
$$

Macierz 4. Odległości między stanowiskami dla wariantu 2

Źródło: opracowanie własne.

Powyższy model cechuje się wartością funkcji celu równą 490. Przesunięcie stanowiska spoza ścieżki krytycznej do lokalizacji najbardziej oddalonej od stanowisk pierwszego i ostatniego w linii przyczyniło się do wyraźnego obniżenia kosztów realizacji transportu w badanej komórce.

Zastosowanie metody Blocha-Schmigalli (zmodyfikowanej metody trójkąta równobocznego) doprowadziło do powstania modelu rozmieszczenia zaprezentowanego na rysunku 9 . 


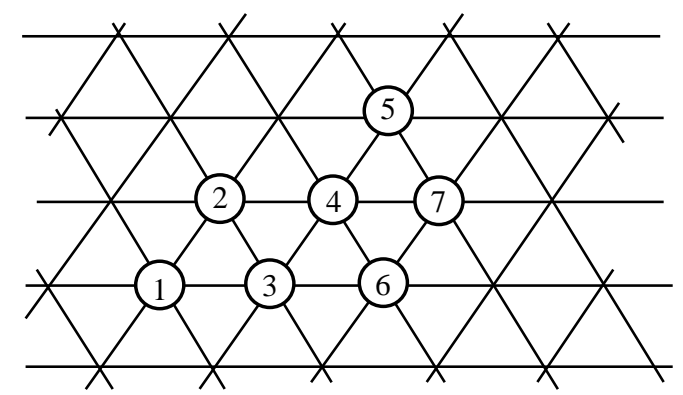

Rysunek 9. Rozmieszczenie stanowisk z zastosowaniem metody Blocha-Schmigalli Źródło: opracowanie własne.

Wartość funkcji celu w tym przypadku wynosi jedynie 360 (wariant 3). Jednak konieczność dokonania dostosowania do U-kształtnego układu stanowisk wyraźnie zmieniła uzyskany wynik (rysunek 10). W rezultacie powstał wariant 4 . Odległości w dostosowanym rozmieszczeniu przedstawia macierz 5.

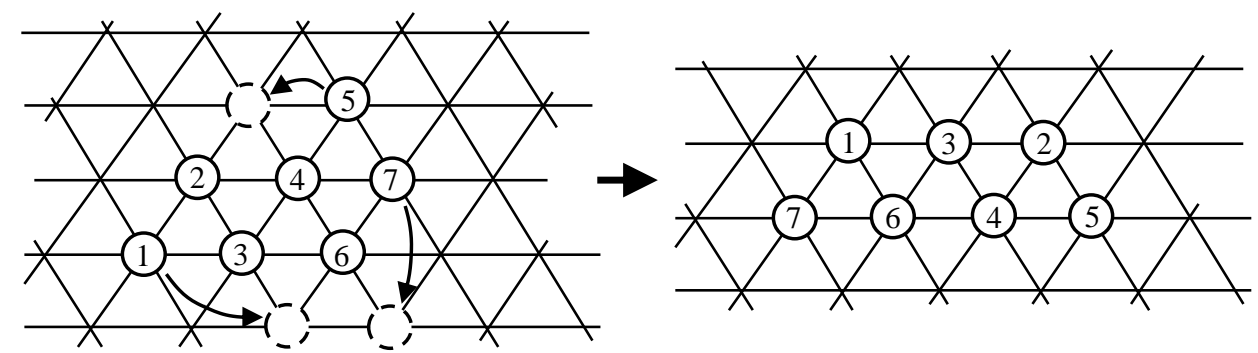

Rysunek 10. Dostosowanie rozmieszczenia do układu U-kształtnego (wariant 4)

Źródło: opracowanie własne.

$$
\left[L_{i j}\right]=\left[\begin{array}{lllllll}
- & 2 & 1 & 2 & 3 & 1 & 1 \\
& - & 1 & 1 & 1 & 2 & 3 \\
& & - & 1 & 2 & 1 & 2 \\
& & & - & 1 & 1 & 2 \\
& & & & - & 2 & 3 \\
& & & & & - & 1 \\
\hline
\end{array}\right.
$$

Macierz 5. Odległości pomiędzy stanowiskami dla wariantu 4 Źródło: opracowanie własne.

Przesunięcie stanowisk spowodowało pogorszenie wartości funkcji celu do wartości 470. 


\section{Zakończenie}

Uzyskane rezultaty dla poszczególnych wariantów rozmieszczenia prezentuje tabela 2 .

Tabela 2. Efekty uzyskane w poszczególnych wariantach rozmieszczenia

\begin{tabular}{|c|c|c|l|}
\hline Wariant & $\begin{array}{c}\text { Wartość } \\
\mathbf{Q} \\
{[/]}\end{array}$ & $\begin{array}{c}\text { Redukcja wartości Q } \\
\text { względem wariantu } \\
\text { początkowego (0) [\%] }\end{array}$ & \multicolumn{1}{c|}{ Opis } \\
\hline 0 & 600 & - & Linia jednorzędowa \\
\hline 1 & 540 & 10 & $\begin{array}{l}\text { Linia U-kształtna bez optymalizacji } \\
\text { rozmieszczenia }\end{array}$ \\
\hline 2 & 490 & 18,3 & $\begin{array}{l}\text { Linia U-kształtna zoptymalizowana } \\
\text { wybraną metodą sieciową }\end{array}$ \\
\hline 3 & 360 & 40 & $\begin{array}{l}\text { Rozmieszczenie optymalne wyznaczone } \\
\text { metodą Blocha-Schmigalli }\end{array}$ \\
\hline 4 & 470 & 21,7 & $\begin{array}{l}\text { Rozmieszczenie optymalne dostosowane } \\
\text { do wymogów linii U-kształtnej }\end{array}$ \\
\hline
\end{tabular}

Źródło: opracowanie własne.

W przeprowadzonej symulacji najlepsze rozmieszczenie stanowisk zostało uzyskane z wykorzystaniem metody Blocha-Schmigalli. Korekta rozmieszczenia, mająca na celu dostosowanie go do wymogów linii U-kształtnej, wyraźnie pogorszyła odpowiadającą mu wartość funkcji kryterium, pozostawiając jednak przewagę nad rozmieszczeniem wyznaczonym z zastosowaniem modelu sieciowego (CPM). Korekta rozmieszczenia w analizowanym przypadku została przeprowadzona w sposób intuicyjny. Przy znacznie większej liczbie stanowisk, tego typu przesuwanie obiektów na siatce może doprowadzić do osiągnięcia rezultatu dalekiego od optymalnego. Określenie lokalizacji z wykorzystaniem modelu sieciowego przyniosło rezultat podobny do otrzymanego z zastosowaniem algorytmu Blocha-Schmigalli. Interesującym jest fakt, że oba rozmieszczenia na siatce istotnie się różnią, jednak każde $\mathrm{z}$ nich cechują bardzo zbliżone koszty realizacji operacji transportowych przy założonym planie produkcji.

W rezultacie zastosowania obu wyżej wskazanych metod uzyskane zostały lepsze wyniki, pod względem redukcji zapotrzebowania na operacje transportowe, w porównaniu $\mathrm{z}$ linią jednorzędową oraz jej prostym przekształceniem w komórkę U-kształtną, które zostało osiągnięte poprzez zbliżenie ze sobą pierwszego i ostatniego stanowiska linii. Na tej podstawie można wyciągnąć wniosek o celowości stosowania nawet prostych 
narzędzi optymalizacji przestrzennego rozmieszczenia przy projektowaniu tego typu komórek.

W omawianym przypadku nie poddano również analizie dodatkowych wariantów U-kształtnego rozmieszczenia stanowisk zaprezentowanych na rysunku 11, czyli wtedy gdy pierwsze i ostatnie stanowiska są zlokalizowane w pobliżu ,środka” komórki.

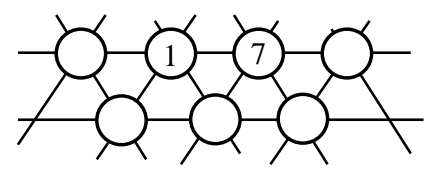

a)

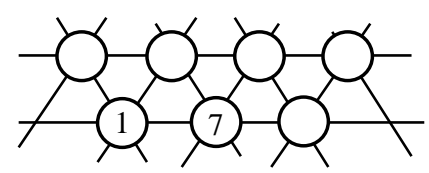

b)

Rysunek 11. Potencjalne rozmieszczenia nie poddane analizie w opracowaniu

Źródło: opracowanie własne.

Należy podkreślić, że w każdym wariancie komórka U-kształtna cechowała się niższą wartością funkcji celu w porównaniu z linią jednorzędową. Potwierdza to zatem słuszność stosowania takiego rozmieszczenia stanowisk. Jako kolejną zaletę należy wskazać, że układ w kształcie litery U umożliwia obserwowanie efektów działania w całej komórce każdemu pracownikowi. Dzięki temu mogą oni łatwo dostrzec wszelkiego rodzaju problemy produkcyjne. Sprzyja to przenoszeniu na nich odpowiedzialności za rezultaty produkcji. W prosty sposób można zatem zdecentralizować nadzór nad przebiegiem procesu [Schary, Skjøtt-Larsen, 2002: 135].

Jak zasygnalizowano w punkcie trzecim niniejszego opracowania, zagadnienie optymalizacji funkcjonowania komórek U-kształtnych było już podejmowane w literaturze przedmiotu w różnym kontekście. Analizy te często dotyczą kwestii przydziału pracowników do stanowisk oraz czasu realizacji poszczególnych operacji. Rzadziej natomiast podejmowana jest problematyka optymalizacji rozmieszczenia stanowisk, którą zajęli się m.in. Władysław Zielecki i Jarosław Sęp [2014], S.S. Gnanavela, Venkatesh Balasubramanian i T.T. Narendran [2015], Yang Li, Naihui He i David Z. Zhang [2019]. Należy również podkreślić, że analizy prowadzone $w$ wyżej wymienionych obszarach są zazwyczaj realizowane z wykorzystaniem modeli teoretycznych a nie na konkretnych zestawach danych. Niniejsze opracowanie stanowi próbę pełniejszego uzupełnienia tej luki. 


\section{BIBLIOGRAFIA}

Banduka N., Mladineo M., Eric M. (2017), Designing a layout using Schmigalla method combined with software tool visTABLE, ,International Journal of Simulation Modelling", vol. 16, nr 3, s. 375-385.

Brzeziński M. (2002), System produkcji nierytmicznej, [w:] M. Brzeziński (red.), Organizacja i sterowanie produkcją. Projektowanie systemów produkcyjnych i procesów sterowania produkcja, Agencja Wydawnicza Placet, Warszawa.

Dudek M. (2016), Projektowanie szczuplych systemów wytwarzania. Wybrane zagadnienia, Difin, Warszawa.

Gnanavela S.S., Balasubramanian V., Narendran T.T. (2015), Suzhal - An alternative layout to improve productivity and worker well-being in labor demanded lean environment, „Procedia Manufacturing”, vol. 3, s. 574-580.

Li Y., He N., Zhang D.Z. (2019), Simulation Based Layout Design and Optimization for Assembly Line System, Proceedings of the World Congress on Engineering, WCE, http://www.iaeng.org/publication/WCE2019/WCE2019_pp315-320.pdf [dostęp: 23.09.2019].

Martyniak Z. (1999), Metody organizacji i zarządzania, Wydawnictwo Akademii Ekonomicznej w Krakowie, Kraków.

Matusek M. (2012), Doskonalenie przepływu materiałów w U-kształtnej linii montażu, „Zeszyty Naukowe Politechniki Śląskiej. Seria Organizacja i Zarządzanie”, nr 1871, s. 192-201.

Miltenburg J. (2001), One-piece flow manufacturing on U-shaped production lines: a tutorial, „IIE Transactions”, vol. 33, s. 303-321.

Ohno K., Nakade K. (1997), Analysis and optimization of a U-shaped production line, „Journal of the Operations Research”, vol. 40, no. 1, s. 90-104.

Özgürler Ş., Güneri A.F., Gülsün B., Yilmaz O., Designing a simple U-shaped production line and analysis of effectiveness, $14^{\text {th }}$ International Research/Expert Conference „Trends in the Development of Machinery and Associated Technology” TMT 2010, Mediterranean Cruise, 11-18 September 2010, s. 253-256.

Pająk E. (2006), Zarządzanie produkcją. Produkt, technologia, organizacja, Wydawnictwo Naukowe PWN, Warszawa.

Potocki A. (1993), Metody przestrzennego organizowania prac administracyjno-biurowych, [w:] Z. Martyniak (red.), Techniki organizatorskie. Zastosowania w organizowaniu prac administracyjno-biurowych, Akademia Ekonomiczna w Krakowie, Kraków.

Prońko J., Soboń A., Zamiar Z. (2008), Zarządzanie produkcja, Wydawnictwo Uniwersytetu Humanistyczno-Przyrodniczego Jana Kochanowskiego, Kielce.

Schary P.B., Skjøtt-Larsen T. (2002), Zarzadzanie globalnym łańcuchem podaży, Wydawnictwo Naukowe PWN, Warszawa.

Sirovetnukul R., Chutima P. (2010), The Impact Of Walking Time On U-Shaped Assembly Line Worker Allocation Problems, ,Engineering Journal”, vol. 14(2), s. 53-78.

Waters D. (2001), Zarzadzanie operacyjne. Towary i ustugi, Wydawnictwo Naukowe PWN, Warszawa.

Zielecki W., Sęp J. (2014), Wspomaganie projektowania linii produkcyjnych U-ksztaltnych metoda programowania sieciowego, [w:] Innowacje w Zarzadzaniu i Inżynierii Produkcji, t. I, Oficyna Wydawnicza Polskiego Towarzystwa Zarządzania Produkcją, Opole. 


\section{LAYOUT OPTIMIZATION IN A U-SHAPED CELL USING NETWORK ANALYSIS AND THE SCHMIGALLA TRIANGULAR METHOD}

\section{SUMMARY}

The workstations layout is important from the point of view of costs and time of production processes. Currently, there are a number of models of placement and methods of its optimization. The U-shaped layout is one of the models used in the design of production cells. This kind of placement became popular with the development of the lean manufacturing concept.

The aim of this study is to demonstrate the possibility of optimizing the positioning of the workstations in the U-line using the network programming method and the Schmigalla triangular method.

Keywords: layout optimization, workstations layout, U-cells, production management, U-shaped line, one piece flow, lean, Schmigalla triangular method. 